\title{
A study of birth defects in a tertiary care teaching hospital at Chennai, India
}

\author{
Mangalageetha Amirthalingam, Padmalatha Dakshnamurthy ${ }^{2 *}$, Vinodhini Shanmugham²
}

\begin{abstract}
${ }^{1}$ Department of Obstetrics and Gynecology, Thoothukudi Medical College, Thoothukudi, Tamil Nadu, India ${ }^{2}$ Department of Obstetrics and Gynecology, Government Kilpauk Medical College Hospital, Kilpauk, Chennai, Tamil Nadu, India
\end{abstract}

Received: 07 May 2017

Revised: 17 May 2017

Accepted: 03 June 2017

\section{*Correspondence: \\ Dr. Padmalatha Dakshnamurthy, \\ E-mail: endork@yahoo.com}

Copyright: (c) the author(s), publisher and licensee Medip Academy. This is an open-access article distributed under the terms of the Creative Commons Attribution Non-Commercial License, which permits unrestricted non-commercial use, distribution, and reproduction in any medium, provided the original work is properly cited.

\section{ABSTRACT}

Background: The Congenital anomalies were estimated to be the fifth largest cause of neonatal deaths in India. The purpose of our study was to determine the proportion and pattern of congenital anomalies and their association with risk factors like maternal diabetes, advanced maternal age and consanguinity among the babies born in a tertiary care teaching hospital in Chennai.

Methods: This study is a cross sectional descriptive study where all the newborns including still born delivered with the presence of congenital anomalies and those fetuses terminated due to detection of presence of congenital anomalies were analyzed. The study was done at the OBG department in a tertiary care center for a period of one year $1^{\text {st }}$ June 2015 to $31^{\text {st }}$ May 2016.

Results: The overall incidence of birth defects were $2.36 \%$, of which musculo skeletal defects $(18.88 \%)$ were commonly found. There was a definite correlation of risk factors with consanguinity showing an incidence of 1.5 times the overall incidence of birth defects (3.54\%) and maternal diabetes mellitus was 6 times the total incidence $(15.3 \%)$. The correlation between the incidence of birth defects and advanced maternal age was not statistically significant in our study.

Conclusions: The study depicts the risk of occurrence of congenital anomalies in the presence of maternal diabetes and in consanguineous marriage and emphasizes on the necessity of adequate screening like first trimester and second trimester ultrasonogram for the early detection of anomalies in the fetus especially if these risk factors are present in the mother.

Keywords: Advanced maternal age, Birth defects, Consanguinity, Maternal diabetes

\section{INTRODUCTION}

Birth defects or otherwise known as congenital anomalies are defined as presence of structural or functional anomalies during the intrauterine life and can be identified prenatally at birth or later in life. They are important causes of childhood death, chronic illness and disability in many countries. It is estimated that around 276000 babies die within 4 weeks of birth every year due to congenital anomalies. ${ }^{1}$ Although $50 \%$ of anomalies cannot be linked to a specific cause, the remaining $50 \%$ have some risk factor associated with it. About $94 \%$ of severe congenital anomalies occur in low- and middleincome countries, where women often lack access to sufficient, nutritious food and may have increased exposure to agents or factors such as infection and alcohol that induce or increase the incidence of abnormal prenatal development. ${ }^{1}$ Consanguinity increases the 
prevalence of rare genetic congenital anomalies and nearly doubles the risk for neonatal and childhood death, intellectual disability and other anomalies in first-cousin unions. ${ }^{1}$

Presence of an anomalous child not only causes an economic burden to the parents but also affects them emotionally leading to lack of peace and harmony.

\section{METHODS}

This study was undertaken to determine the proportion and pattern of congenital anomalies reported at a tertiary care teaching hospital in Chennai, Tamilnadu, India and to analyze the association of maternal risk factors like diabetes, consanguinity and increased age with the anomalies. The Primary objective was to determine the incidence and to categorize the birth defects system wise. The Secondary objective was to assess the association of birth defects with consanguinity, maternal diabetes and increased maternal age.

After obtaining permission and clearance from institute' $\mathrm{s}$ scientific review board and ethics committee, the study was started. This cross sectional descriptive study was done to determine the incidence of congenital anomalies reported in the OBG unit of a tertiary care hospital for a period of one year from $1^{\text {st }}$ June 2015 to $31^{\text {st }}$ May 2016.All the babies and those born with congenital anomalies both live born and still born and those fetuses that were terminated for the presence of lethal anomalies were included in the study. All the babies included in the study were examined and assessed systematically for the presence of congenital anomalies.

Clinical evaluation of babies by the pediatrician and other appropriate investigations such as radiography, ultrasonography, echocardiography and chromosomal analysis etc., were used to identify and confirm the birth defects. System wise distribution of the anomalies was performed. For each case, a detailed antenatal and maternal history including the age of the mothers, the history of consanguinity and the presence of diabetes mellitus were obtained by reviewing the maternal and labour ward records and by interviewing the parents.

\section{Statistical analysis}

Data was entered into excel data sheet and appropriate statistical analysis was performed. Proportion was calculated and the association was tested with Chi-square test and Fisher's exact test. $\mathrm{P}<0.05$ was considered to be statistically significant.

\section{RESULTS}

The total number of deliveries during the one year period were 6056 including live births (twins) and still borns. The number of fetuses with birth defects were 143, amounting to an overall incidence of $2.36 \%$. The anomaly involving the Musculo-skeletal system (18.88\%) was the most common followed by Genito-Urinary $(16.78 \%)$ and central nervous system (14.68\%) (Table 1, and 2).

Table 1: Analysis of the birth defects $(n=143)$.

\begin{tabular}{|lll|}
\hline Major birth defects & Number & $\%$ \\
\hline GIT & 15 & 10.48 \\
\hline GUT & 21 & 14.68 \\
\hline Cardiac & 24 & 16.78 \\
\hline Respiratory & 19 & 13.28 \\
\hline Multiple & 3 & 2.09 \\
\hline Minor birth defects & 7 & 4.89 \\
\hline Hydrops fetalis & & \\
\hline Cyctic hygroma & 2 & 1.39 \\
\hline Musculo skeletal & 2 & 1.39 \\
\hline Chromosomal & 27 & 18.88 \\
\hline Downs & 9 & 6.29 \\
\hline Fetal hydantoin syndrome & 2 & 1.39 \\
\hline Laryngomalacia & 1 & 0.69 \\
\hline Collodion & 4 & 2.79 \\
\hline Dacrocyctitis & 1 & 0.69 \\
\hline Skin & 1 & 0.69 \\
\hline Single umblical artery & 2 & 1.39 \\
\hline
\end{tabular}

In musculoskeletal system, foot deformity- CTEV was the most common anomaly, in genitourinary system, hydronephrosis of kidneys was the common anomaly and in CNS, neural tube defects were the common anomaly found in present study.

The presence of associated maternal risk factors were also analysed and the observations made are that the presence of consanguinity was $3.49 \%,(p=0.038)$ and maternal diabetes was $15.3 \%(\mathrm{p}=0.001)$ among the babies with birth defects and was found to be statistically significant and the incidence in elderly gravidas was $1.39 \%(\mathrm{p}=0.072)$ which is statistically not significant. (Table 3).

\section{DISCUSSION}

In present study, the total and individual incidence of birth defects were analysed. The overall incidence of birth defects was $2.36 \%$ which compares well with the observations of Marden et al 2-4\%, Goravalingappa and Nashi 3.13\%, Ghose et al 1.5\%, Graham 2\%, Mishra PC et al $1.46 \%$, Mohanty et al $1.61 \%$, Shah et al $3.6 \%$. $^{2-7}$

The studies of Ghose et al and Mohanty et al had found a higher incidence of musculoskeletal system malformations which is comparable with our study also. Shatanik Sarkar et al reported a higher incidence of talipes among the musculoskeletal system as reported in present study. ${ }^{8}$ Consanguineous marriages also play a vital role in the development of birth defect. ${ }^{9}$ In present study also, incidence of birth defects was more when 
born out of consanguineous marriages as seen in other studies. ${ }^{10}$

Table 2: System-wise categorisation of birth defects.

\begin{tabular}{|c|c|c|}
\hline System & Number & $\%$ \\
\hline \multicolumn{3}{|l|}{ Musculo-skeletal system } \\
\hline CTEV & 6 & 4.19 \\
\hline Polydactyly & 2 & 1.39 \\
\hline Syndactyly & 1 & 0.67 \\
\hline Phocomelia & 2 & 1.39 \\
\hline Genu Recurvatum & 5 & 3.49 \\
\hline Erb’s Palsy & 3 & 2.09 \\
\hline Limb abnormalities & 8 & 5.59 \\
\hline \multicolumn{3}{|l|}{ Gastro-intestinal system } \\
\hline Cleft lip & 5 & 3.5 \\
\hline Imperforate anus & 4 & 2.8 \\
\hline Gastrochisis & 1 & 0.7 \\
\hline Omphalocele & 1 & 0.7 \\
\hline Duodenal atresia & 2 & 1.4 \\
\hline Intestinal obstruction & 3 & 2.1 \\
\hline \multicolumn{3}{|l|}{ Genito urinary system } \\
\hline Hydronephrosis & 5 & 3.5 \\
\hline Ambiguous genetalia & 2 & 1.4 \\
\hline Polycystic kidney & 2 & 1.4 \\
\hline Undescended testis & 8 & 5.7 \\
\hline Hydrocele & 3 & 2.1 \\
\hline Hypospadias & 1 & 0.7 \\
\hline Inguinal hernia & 1 & 0.7 \\
\hline Ovarian cyst & 1 & 0.7 \\
\hline \multicolumn{3}{|l|}{ Cardiovascular system } \\
\hline Cyanotic & 1 & 0.69 \\
\hline Acyanotic & 11 & 7.69 \\
\hline Dextro cardia & 3 & 2.09 \\
\hline Others & 4 & 2.79 \\
\hline \multicolumn{3}{|l|}{ Skin } \\
\hline Nevus & 1 & 0.69 \\
\hline Cavernous hemangioma & 1 & 0.69 \\
\hline \multicolumn{3}{|l|}{ Respiratory system } \\
\hline Congenital diaphragmatic hernia & 2 & 1.39 \\
\hline TE fistula & 1 & 0.69 \\
\hline \multicolumn{3}{|l|}{ Central nervous system } \\
\hline Neural tube defects & 14 & 10 \\
\hline Dandy walker syndrome & 3 & 2.1 \\
\hline \multicolumn{3}{|l|}{ Others } \\
\hline Downs syndrome & 2 & 1.39 \\
\hline Fetal hydantoin syndrome & 1 & 0.69 \\
\hline Single umblical artery & 3 & 2.09 \\
\hline Hydrops fetalis & 2 & 1.39 \\
\hline Cystic hygroma & 2 & 1.39 \\
\hline Collodion baby & 1 & 0.69 \\
\hline Laryngomalacia & 4 & 2.79 \\
\hline Dacrocystitis & 1 & 0.69 \\
\hline Multiple system affected & 7 & 4.89 \\
\hline Chromosomal abnormalities & 9 & 6.29 \\
\hline
\end{tabular}

Congenital anomalies of the central nervous system (CNS), heart, and renal and urinary tracts, lower limb reduction defects, axial skeleton defects, and caudal dysgenesis complex are more frequent among the children of mothers with pregestational diabetes than among children with non-diabetic mothers.

Table 3: Maternal risk factors and birth defects.

\begin{tabular}{|c|c|c|c|c|c|}
\hline $\begin{array}{l}\text { Birth } \\
\text { defects }\end{array}$ & Groups & Yes & No & $\chi^{2}$ & $\begin{array}{l}\mathbf{P} \\
\text { value }\end{array}$ \\
\hline \multirow{2}{*}{ Consanguinity } & Present & 5 & 487 & \multirow{2}{*}{4.282} & \multirow{2}{*}{0.038} \\
\hline & Absent & 138 & 5382 & & \\
\hline \multirow{2}{*}{$\begin{array}{l}\text { Maternal } \\
\text { diabetes }\end{array}$} & Present & 22 & 594 & \multirow{2}{*}{40205} & \multirow{2}{*}{0.040} \\
\hline & Absent & 121 & 616 & & \\
\hline \multirow{2}{*}{$\begin{array}{l}\text { Advanced } \\
\text { maternal age }\end{array}$} & $<35 \mathrm{yrs}$ & 141 & 5603 & \multirow{2}{*}{3.218} & \multirow{2}{*}{0.072} \\
\hline & $\geq 35 \mathrm{yrs}$ & 2 & 266 & & \\
\hline
\end{tabular}

It has been postulated that hyperglycemia-induced teratogenesis is caused by several mechanisms, such as functional deficiencies of arachidonic acid and myoinositol; inhibition of the cellular uptake of dehydroascorbic acid and increased non-enzymatic glycosylation of embryonic proteins; decreased catalase activity and increased substrate-induced free-oxygen radical production; and abnormal levels of trace metals. ${ }^{11}$

Bai $\mathrm{S}$ et al stated a greater incidence of birth defects in the babies born to mothers aged over 35 years, whereas Dutta et al highlighted statistically insignificant association of increased maternal age and congenital anomalies. ${ }^{12,13}$ The relationship between maternal age and babies born with congenital malformations, in present study also revealed a statistically insignificant data.

In present study, it was identified that the incidence of congenital malformations was higher in male babies $(58 \%)$ when compared to the female babies (39.8\%) with ambiguous genitalia amounting to $2.04 \%$. Mohanty et al also reported higher incidence of congenital malformations in male babies $(1.91 \%)$ than in female babies $(1.27 \%) .{ }^{6}$ Male preponderance was similar to the other studies. ${ }^{6}$ It might be due to the fact that the female babies were afflicted with more lethal birth defects and could not survive to be born with signs of life.

\section{CONCLUSION}

Birth defects are easily detectable by a routine screening in the first and second trimester. Public health measures for detection and prevention of birth defects can help to reduce this burden greatly. Prevention of conception of an anomalous childis also possible by adequate preconception counselling regarding control of diabetes and avoidance of marriages among close relatives and use of preconception folic acid supplements.Increasing awareness about maternal care during pregnancy, educational programs on congenital malformations and the consequences of consanguineous marriages need to be highlighted to decrease the incidence of congenital anomalies and their comorbidities. 
Funding: No funding sources

Conflict of interest: None declared

Ethical approval: The study was approved by the Institutional Ethics Committee

\section{REFERENCES}

1. World Health Organisation. Congenital anomalies. Fact sheets. Available at www.who.int/mediacentre/factsheets/fs370/en/.

Accessed on 10th May 2017.

2. Clark RD, Eteson DJ. Congenital anomalies. In Schaffer and Avery's Diseases of the Newborn WB Saunders, Philadelphia;1991:159-191.

3. Goravalingappa JP, Nashi HK; Congenital Anomalies in a study of 2398 consecutive births. Indian J Med Res. 1979;69:140.

4. Ghosh S, Bhargava SK, Bhtani R. Congenital anomalies in longitudinally studied birth cohort in a urban community. Indian J Med Res. 1985;82:427.

5. Mishra PC, Baveja R. Congenital anomalies in New borns: a prospective study. Indian Pediatr. 1989;26:97.

6. Mohanty C. Congenital anomalies in new born. A study of 10,874 consecutive birth. J Anatomy Soc India. 1989;38:2.

7. Shah K, Pensi CA. Study of incidence of congenital anomalies in newborns. Guj Med J. 2013;68(2):97-9.
8. Sarkar S, Patra C, Dasgupta MK, Nayek K, Karmakar PR. Prevalence of congenital anomalies in neonates and associated risk factors in a tertiary care hospital in eastern India. J Clin Neonatol. 2013;2(3):131.

9. Hudgins L, Cassidy SB. Congenital anomalies. In: Martin RJ, Fanaroff AA, Walsh MC, editors. Neonatal-Perinatal Medicine. $8^{\text {th }}$ ed. Philadelphia: Mosby-Elsevier; 2006:561-81.

10. Mathur BC, Karan S, Vijaya Devi KK. Congenital malformations in the newborn. Indian Pediatr. 1975;12:179-83.

11. Chen CP. Congenital malformations associated with maternal diabetes. Taiwanese J Obstet Gynecol. 2005;44(1):1-7

12. Suguna Bai NS, Mascarene M, Syamalan K, Nair PM. An etiological study of congenital malformation in the newborn. Indian Pediatr. 1982;19:1003-7.

13. Dutta V, Chaturvedi P. Congenital malformations in rural Maharashtra. Indian Pediatr. 2000;37:998-1001.

Cite this article as: Mangalageetha A, Padmalatha D, Vinodhini S. A study of birth defects in a tertiary care teaching hospital at Chennai, India. Int J Reprod Contracept Obstet Gynecol 2017;6:3067-70. 